\title{
Molecular Characterization of Escherichia coli Isolates from Humans and Chickens in the Chungcheong Area Using MLST Analysis
}

\author{
Semi Kim ${ }^{1}$, Ji Youn Sung ${ }^{2}$, and Seung-Gu Choi ${ }^{3}$ \\ ${ }^{1}$ Department of Laboratory Medicine, Sun Medical Center, Daejeon 301-725, Korea \\ ${ }^{2}$ Department of Biomedical Laboratory Science, Far East University, Eumseong 369-700, Korea \\ ${ }^{3}$ Department of Biomedical Laboratory Science, Shin Han University, Uijeongbu 480-701, Korea
}

\section{충청지역에서 분리된 사람 유래 대장균 및 닭 유래 대장균의 항균제 내성 및 MLST를 이용한 유전형의 분포 조사}

\author{
김세미 ${ }^{1}$, 성지연 $^{2}$, 최승구 $^{3}$ \\ ${ }^{1}$ 대전선병원 진단검사의학과, ${ }^{2}$ 극동대학교 임상병리학과, ${ }^{3}$ 신한대학교 임상병리학과
}

\begin{abstract}
Antimicrobial resistant bacteria has recently emerged and been disseminated in livestock environments because of excessive use of antimicrobial agents for the therapeutic and growth promotion purposes to food animals. In particular, there is potential for multidrug-resistant bacteria that can be transmitted from animals to mankind. In this study, we investigated the genotypes of $E$. colistrains isolated from humans and chickens using multi-locus sequence typing (MLST) and antimicrobial resistance patterns by disk diffusion method along with integron study involving antimicrobial resistance mechanisms. From July 2013 to July 2014, E. colistrains isolated from clinical specimens $(n=44)$ and poultry chickens $(n=34)$. ST131 $(n=20)$ was most common in human-derived E. coli.ST752 ( $\mathrm{n}=7$ ) was most common in chicken-derived $E$. coli, with four isolates each for ST117, ST189, and ST69. Of the 44 E. colistrains isolated from humans, 25 of had a class 1 integron, as opposed to only 11 of 34 strains in the E. coli isolated from chickens. There were differences in genotypes and antimicrobial resistance patterns between the chicken-derived and the human-derived E. coli.
\end{abstract}

Keywords: MLST, Integron, E. coli, Chickens

This is an Open Access article distributed under the terms of the Creative Commons Attribution Non-Commercial License (http://creativecommons.org/licenses/by-nc/4.0) which permits unrestricted non-commercial use, distribution, and reproduction in any medium, provided the original work is properly cited

Copyright (C) 2015 The Korean Society for Clinical Laboratory Science. All rights reserved.
Corresponding author: Ji Youn Sung Department of Biomedical Laboratory Science, Far East University, Eumseong 369-700, Korea.

Tel: 82-43-879-3668

E-mail: azaza72@naver.com

Received: May 20, 2015

Revised: None

Accepted: June 2, 2015
서 론

Ampicillin의 개발 이후 대장균에 의한 감염증 치료를 위해 사람 과 동물 모두에게 $\beta$-lactam 계열의 항균제가 많이 사용되어왔는 데, 최근 extended-spectrum $\beta$-lactamases (ESBL) 생성 대장균 의 증가로 감염증 치료를 위한 항균제의 선택이 어려운 경우가 많
아 졌다(Hong 등, 2001; Song 등, 2009; Sung 등, 2013; Kim 등, 2014). 특히 닭과 같은 가축에서의 $\mathrm{ESBL}$ 생성균의 보고가 증가하 고 있는데, 이는 대장균에 의해 발생하는 닭 대장균증으로 인한 생 산성 저하 및 높은 폐사율(약 20\%)을 방지하기 위해 치료 및 예방 목 적으로 항균제를 광범위하게 사용했기 때문이다(Dho 등, 1999; Lee 등, 2001). 인수공통 감염균의 동물과 사람사이의 전파 가능성 
이 보고되고 있고(Winokur 등, 2000; Rodriguez 등, 2003), 대장 균은 사람과 동물 모두를 숙주로 하는 만큼 닭에서의 항균제 내성 대장균의 증가는 임상적으로도 문제가 될 것으로 예상 된다.

병원균이 분리되었을 때 근원을 찾아 더 이상의 확산을 막는 것 이 무엇보다 중요하다. 병원균의 근원을 찾기 위해 최근에는 고전 적인 역학조사 방법 위에 분자생물학적인 기법을 더하여 병원균의 유전형을 비교함으로써 보다 합리적이고 과학적인 분석이 가능해 졌다. 가장 대표적인 방법 중 하나가 multi-locus sequence typing (MLST) 이다. 이 방법은 housekeeping gene을 기반으로 염기서 열의 다형성을 비교하여 진화학적 다양성을 확인하는 방법으로 (Maiden 등, 1998), 대장균의 경우 7개의 housekeeping gene을 사용하는데, 임상 유래 대장균의 MLST 분석결과는 많이 보고되고 있으나 닭 유래 대장균의 MLST 분석은 매우 드문 편이다.

Integron은 장소-특이적인 재조합 기전에 의해 많은 항균제 내 성 유전자들을 축적, 발현 및 전파 할 수 있다. 그래서 integron 보유 감염균들은 항균제 내성유전자를 다른 균주에게 옮길 수 있는데 (Recchia와 Hall, 1995; Richet 등, 2001), 이로 인한 항균제 내성 세균의 출현 및 확산은 세균에 의한 감염증 치료에 많은 어려움을 가중시킬 수 있다.

본 연구에서는 충청지역의 한 대학병원의 임상검체에서 분리된 대장균 및 양계농장에서 사육되는 닭에서 분리된 대장균을 대상으 로 MLST를 시행하여 균주를 동정 및 분류하고 항균제 감수성 검사 및 integron의 존재여부를 조사하여 내성현황 및 대장균 유전형의
분포를 확인하여, 항균제 내성 대장균의 확산 방지책을 마련하는데 필요한 기초자료를 제공하고자 하였다

\section{재료 및 방법}

\section{1. 균주 수집}

2013년 7월부터 2014년 8월까지 충청지역 1개 대학병원에 의 뢰 된 임상검체에서 분리된 대장균 중 cefotaxime 또는 ceftazidime 에 내성을 보인 44주와, 충청지역 양계 농장에서 사육되는 닭에서 분리된 대장균 34 주를 대상으로 하였다. 균주는 분리된 순서대로 수집하였으며, 동일 환자 및 닭에서 반복 분리된 균주는 수집대상 에서 제외하였다. 분리된 균주의 동정은 집락의 형태 및 Vitek 2 automated ID system (bioMèrieux Vitek Inc., Hazelwood, $\mathrm{MO}, \mathrm{USA}$ )를 이용한 생화학적 방법으로 확인하였다.

\section{2. 항균제 감수성 시험}

Clinical and Laboratory Standards Institute (CLSI) 지침에 따 라 디스크 확산법으로 항균제 감수성 시험을 하였다(CLSI, 2013). 시험한 항균제는 amikacin (AN), gentamicin (GM), cefotaxime (CTX), ceftazidime (CAZ), cefepime (FEP), imipenem (IMP), ampicillin (AMP) 및 ciprofloxacin (CIP) 이다. 정도관리를 위해 서 Escherichia coli ATCC25922와 Pseudomonas aeruginosa ATCC 27853을 동시에 시험하여 허용 범위 내에 있는지를 확인하였다.

Table 1. Oligonucleotide primers for MLST and the detection of integrons

\begin{tabular}{|c|c|c|c|}
\hline Target gene & Primer pairs & Sequence $\left(5^{\prime} \sim 3^{\prime}\right)$ & Reference \\
\hline \multirow[t]{2}{*}{ Class 1 integrons } & hep58 & TCATGGCTTGTTATGACTGT & White PA et al, 2001 \\
\hline & hep59 & GTAGGGCTTATTATGCACGC & \\
\hline \multirow[t]{2}{*}{ Class 2 integrons } & hep51 & GATGCCATCGCAAGTACGAG & White PA et al, 2001 \\
\hline & hep74 & CGGGATCCCGGACGGCATGCACGATTTGTA & \\
\hline \multirow[t]{2}{*}{ Class 3 integrons } & $\ln 3 \mathrm{~F}$ & GCCTCCGGCAGCGACTTTCAG & Dillon et al, 2005 \\
\hline & $\ln 3 \mathrm{R}$ & ACGGATCTGCCAAACCTGACT & \\
\hline \multirow[t]{2}{*}{$a d k$} & adkF & ATTCTGCTTGGCGCTCCGGG & Tartof SY et al, 2005 \\
\hline & adkR & CCGTCAACTTTCGCGTATTT & \\
\hline \multirow[t]{2}{*}{ fumc } & fumCF & TCACAGGTCGCCAGCGCTTC & Tartof SY et al, 2005 \\
\hline & fumCR & GTACGCAGCGAAAAAGATTC & \\
\hline \multirow[t]{2}{*}{ gyrB } & gyrBF & TCGGCGACACGGATGACGGC & Tartof SY et al, 2005 \\
\hline & gyrBR & ATCAGGCCTTCACGCGCATC & \\
\hline \multirow[t]{2}{*}{$i c d$} & $\mathrm{icdF}$ & ATGGAAAGTAAAGTAGTTGTTCCGGCACA & Tartof SY et al, 2005 \\
\hline & $\mathrm{icdR}$ & GGACGCAGCAGGATCTGTT & \\
\hline \multirow[t]{2}{*}{$m d h$} & mdhF & ATGAAAGTCGCAGTCCTCGGCGCTGCTGGCGG & Tartof SY et al, 2005 \\
\hline & mdhR & TTAACGAACTCCTGCCCCAGAGCGATATCTTTCTT & \\
\hline \multirow[t]{2}{*}{ purA } & purAF & CGCGCTGATGAAAGAGATGA & Tartof SY et al, 2005 \\
\hline & purAR & CATACGGTAAGCCACGCAGA & \\
\hline \multirow[t]{2}{*}{ recA } & recAF & CGCATTCGCTTTACCCTGACC & Tartof SY et al, 2005 \\
\hline & recaAR & TCGTCGAAATCTACGGACCGGA & \\
\hline
\end{tabular}

Abbreviations: $F$, forward; $R$, reverse. 


\section{3. 분자생물학적 방법에 의한 integron 유전자 카세트 분석}

Class 1, 2, 및 3에 속하는 integron을 검출하기 위해 기존의 시 발체(Table 1)를 사용하여 중합효소연쇄반응(polymerase chain reaction, PCR)과 염기서열분석을 시행하였다.

대상 균주를 brain heart infusion broth (Difco, Cockeysville, $\mathrm{MD}, \mathrm{USA}$ )에 접종하여 $37^{\circ} \mathrm{C}$ 에서 하룻밤 진탕배양한 후 배양액으 로부터 DNA extraction kit (Bioneer, Daejeon, Korea)을 사용하 여 염색체 DNA를 추출하였다.

DNA 추출액 $(5 \mu \mathrm{L}), 10 \times$ Taq buffer $(2.5 \mu \mathrm{L}), 10 \mathrm{mM} \mathrm{dNTP}$ $\operatorname{mix}(0.5 \mu \mathrm{L})$, primer 각 $10 \mathrm{pmol}, 0.7 \mathrm{U}$ Taq DNA polymerase (Bioneer) 및 증류수를 혼합하여 총 부피 $25 \mathrm{~mL}$ 의 반응 용액을 만 들었다. SEEAMP (Seegene, Seoul, Korea)로 증폭 반응시키고, 각 각의 PCR 생산물을 ethidium bromide가 포함된 1.5\% agarose gel에서 40분간 전기영동 하여 밴드를 확인하였다. 증폭산물을 PCR purification kit (Bioneer)로 정제 후, BigDye Terminator Cycle Sequencing Kit (PEApplied Biosystems, Foster City, CA, USA)와 $\mathrm{ABI}$ PRISM 3730xl DNA analyzer (PE Applied Biosystems)를 이용하여 염기 서열을 분석하였다.

\section{MLST}

균주들의 sequence type (ST)을 결정짓기 위하여 Achtman의 기법을 따라 7개의 housekeeping gene인 $\mathrm{adk}$, fum $C, \mathrm{gyr} B, \mathrm{icd}$, $m d h$, purA, 그리고 recA를 이용하였다(Tartof SY 등, 2005). ST
번호의 부여는 MLST 사이트(http://mlst.warwick.ac.uk/mlst/) 에서 allele sequence를 비교하여 시행하였다.

\section{결 과}

\section{1. 항균제 감수성 양상}

시험 기간 동안 환자 임상 검체에 CTX 또는 CAZ에 내성인 대장 균 44주가 분리되었고, 닭에서는 대장균 43 주가 분리되었다. 이들 총 87 주를 대상으로 항균제 감수성 시험을 한 결과 사람유래 대장 균의 경우 ampicillin 100.0\%, amikacin $18.2 \%$, gentamicin $47.8 \%$, cefotaxime $100.0 \%$, ceftazidime $65.9 \%$, cefepime 34.1\%, imipenem 0.0\%, ciprofloxacin 63.6\%에서 비감수성 내 지는 내성을 보였고, 닭 유래 대장균의 경우 ampicillin $76.5 \%$, amikacin 67.6\%, gentamicin 64.3\%, cefotaxime 47.0\%, ceftazidime $8.8 \%$, cefepime $2.9 \%$, imipenem $0.0 \%$, ciprofloxacin $94.1 \%$ 에서 비감수성 내지는 내성을 보였다(Table 3).

\section{ST type의 비교 및 다양성}

사람유래 대장균 총 44 주 중 $\mathrm{ST} 131(\mathrm{n}=20)$ 이 가장 많았고, 그 다 음으로 ST38 ( $=15)$, ST405 ( $=3), \operatorname{ST} 69(n=2), \operatorname{ST} 95(n=2)$, $\mathrm{ST} 1193$ (n=1), 그리고 ST2329 (n=1) 였다. 닭 유래 대장균 총 34주 중 ST752 (n=7)가 가장 많았고, 그 다음으로 ST69 (n=4), ST117 $(n=4), \operatorname{ST} 189(n=4), \operatorname{ST} 57(n=3)$, ST10 $(n=2), \operatorname{ST} 641(n=2)$, ST1140(n=2), ST34 (n=2)이었다. 이 외에 ST162, ST58, ST212,

Table 2. Distribution of STs of E. coli from humans and chickens

\begin{tabular}{|c|c|c|c|c|}
\hline STs (allele profile) & ST complex & Humans & Chickens & Total \\
\hline ST131（53-40-47-13-36-28-29） & ST131 Cplx & 20 & & 20 \\
\hline ST38 (4-26-2-25-5-5-19) & ST38 Cplx & 15 & & 15 \\
\hline ST405 (35-37-29-25-4-5-73) & ST405 Cplx & 3 & & 3 \\
\hline ST69 (21-35-27-6-5-5-4) & ST69 Cplx & 2 & 4 & 6 \\
\hline ST95 (37-38-19-37-17-11-26) & ST95 Cplx & 2 & & 2 \\
\hline ST2329 (9-6-33-18-7-8-7) & & 1 & & 1 \\
\hline ST1193 (14-14-10-200-17-7-10) & & 1 & & 1 \\
\hline ST752 (10-11-4-8-8-8-49) & & & 7 & 7 \\
\hline ST117 (20-45-41-43-5-32-2) & & & 4 & 4 \\
\hline ST189 (10-27-5-10-12-8-49) & ST165 Cplx & & 4 & 4 \\
\hline ST57 $(6-31-5-28-1-1-2)$ & ST350 Cplx & & 3 & 3 \\
\hline ST10 (10-11-4-8-8-8-2) & ST10 Cplx & & 2 & 2 \\
\hline ST641 (9-6-33-131-24-8-7) & ST86 Cplx & & 2 & 2 \\
\hline ST1140 (83-23-164-181-80-1-42) & & & 2 & 2 \\
\hline ST34 (10-11-4-1-8-8-2) & ST10 Cplx & & 2 & 2 \\
\hline ST162 (9-65-5-1-9-13-6) & ST469 Cplx & & 1 & 1 \\
\hline ST58 (6-4-4-16-24-8-14) & ST155 Cplx & & 1 & 1 \\
\hline ST212 (6-29-4-18-11-8-6) & & & 1 & 1 \\
\hline ST93 (6-11-4-10-7-8-6) & ST168 Cplx & & 1 & 1 \\
\hline
\end{tabular}

Abbreviations: STs, sequence types; Cplx, complex. 
Table 3. Antimicrobial susceptibility of Escherichia coli from humans and chickens

\begin{tabular}{|c|c|c|c|c|c|c|}
\hline \multirow{3}{*}{$\begin{array}{l}\text { Antimicrobial } \\
\text { agents }\end{array}$} & \multicolumn{6}{|c|}{ Antimicrobial susceptibility (\%) } \\
\hline & \multicolumn{3}{|c|}{ Isolates from human } & \multicolumn{3}{|c|}{ Isolates from chicken } \\
\hline & Susceptible & Intermediate & Resistant & Susceptible & Intermediate & Resistant \\
\hline Ampicillin & 0.0 & 0.0 & 100.0 & 23.5 & 70.6 & 5.9 \\
\hline Cefotaxime & 0.0 & 4.6 & 95.4 & 52.9 & 38.2 & 8.8 \\
\hline ceftazidime & 34.1 & 31.8 & 34.1 & 91.2 & 5.9 & 2.9 \\
\hline cefepime & 65.9 & 0.0 & 34.1 & 97.1 & 0.0 & 2.9 \\
\hline Amikicin & 81.8 & 2.3 & 15.9 & 32.4 & 38.2 & 29.4 \\
\hline Gentamicin & 52.2 & 2.3 & 45.5 & 41.2 & 40.8 & 23.5 \\
\hline Ciprofloxacin & 0.0 & 0.0 & 63.6 & 5.9 & 0.0 & 94.1 \\
\hline Imipenem & 100 & 100 & 0.0 & 100 & 0.0 & 0.0 \\
\hline
\end{tabular}

ST93도 각 한 주씩 분리되었다(Table 2, Fig. 1).

\section{Integron 검출과 유전자 카세트의 유전형 확인}

사람 유래 대장균 총 26 주, 닭 유래 대장균 11 주에서 class 1 integron이 검출되었다. 사람 유래 대장균의 경우 1 주를 제외한 25 주가 gene cassette array인 $d f \mathrm{~A} 17-a a d A 5$ 를 동반하였고, 닭 유 래 대장균의 경우 dffA17-aadA5 ( $\mathrm{n}=4), d f \mathrm{~A} 1$-aadA1 $(\mathrm{n}=3)$, dfrA17 $(\mathrm{n}=2)$ 등 다양한 gene cassette array를 동반하였다. 반면 에 닭 유래 및 사람 유래 대장균 모두에서 class 2 및 3 integron은 검출되지 않았다(Fig. 1).

\section{고 찰}

항균제는 사람과 동물의 치료 및 예방 목적 뿐 만 아니라 가축의 사육에서 성장촉진제의 역할 및 농수산물에도 널리 쓰이는데, 항균 제의 사용량이 병원보다 병원 이외의 장소에서 소비되는 양이 더 많은 것으로 보고되고 있고 유럽이나 미국의 경우 약 $50 ~ 80 \%$ 이 상이 동물에게 사용되고 있다고 한다. 이로 인해 내성 세균의 발현 이 증가되고 동물에서 사람으로 항균제 내성세균이 전파되어 심각 한 사회문제가 되고 있다고 보고 하였다(Neu HC, 1992; Klare 등, 1995; Witte W, 1998; Van 등, 2000; Willerms 등, 2000).

이번 시험 기간 동안 분리된 사람유래 대장균 44 주와 닭 유래 대 장균 43 주에 대하여 항균제 감수성 시험을 한 결과, 사람유래 대장 균의 경우 cefotaxime을 포함하여 평균 4.1개의 항균제에 내성을 보인 반면, 닭 유래 대장균의 경우 평균 3.5 개의 항균제에 내성을 보 였다. 사람유래 대장균의 경우 cefotaxime과 ceftazidime을 포함 하여 amipicillin과 ciprofloxacin에서 각 $100.0 \%$ 와 $63.6 \%$ 의 내 성빈도를 보였고, 닭 유래 대장균의 경우 imipenem, cefepime 및 ceftazidime을 제외한 나머지 항균제에서 각 $64.3 \%$ 94.1\%의 비 감수성 내지는 내성을 보이는 것으로 나타났다. 두 그룹간의 내성
빈도를 비교하면 ampicillin과 cefepime의 경우는 사람 유래 대장 균의 내성 빈도가 높았으나, aminoglycoside계인 amikacin과 gentamicin, 그리고 quinolone계 항균제인 ciprofloxacin의 경 우는 닭 유래 대장균에서 내성 빈도가 높았다. 특히 ciprofloxacin 의 경우는 닭 유래 대장균 중 $94.1 \%$ 에서 내성을 보여 내성빈도가 매우 높게 나타났다. 항균제의 사용과 내성균의 출현과는 밀접한 관계가 있는 것으로 많이 보고되고 있는데(Neu HC, 1992; Witte $\mathrm{W}, 1998$ ) 위의 결과로 미루어 양계농장에서 항균제의 과다 사용으 로 인하여 내성균의 출현이 증가하였음을 예상하게 한다.

MLST 분석 결과 다양한 유형의 ST 유형이 나왔는데, 사람유래 대장균에서는 ST131이 가장 많았는데 $(\mathrm{n}=20)$ 이 유형은 전세계적 으로 $\mathrm{ESBL}$ 생성 대장균에서 가장 많이 나오는 유형이다. 그 다음으 로 ST38이 15주 나왔는데, 많은 경우의 다른 나라나 지역이 ST131 이외에 ST 405 의 비율이 높은 것에 비하여 우리 지역에서는 ST38 의 분리 비율이 높은 편이었다. 닭의 경우 ST752가 7주로 가장 많 이 분리 되었는데, 특별히 많이 분리되는 유전자형은 없었고 다양 한 유형으로 분리되었다. ST69의 경우 사람 유래 대장균 $(\mathrm{n}=2)$ 과 닭 유래 대장균 $(\mathrm{n}=4)$ 에서 모두 분리되었는데, 특이하게도 계통수에 서는 같은 군으로 묶이지 않았다. 일반적인 경우 ST별로 같은 군으 로 묶이지만 본 연구에서는 특이적으로 동일한 ST임데도 불구하고 사람유래 대장균과 닭 유래 대장균의 염기서열에 큰 차이가 있음이 확인되었다. 하지만 같은 ST 번호를 가지고 있다는 것은 진화학적 유래가 같은 매우 유사한 균임을 의미하므로 사람 유래 대장균과 닭 유래 대장균에서 같은 $\mathrm{ST}$ 가 검출되었다는 것은 사람과 동물 사 이에 세균의 전파 및 확산이 가능하다는 것을 재증명한 결과라 하 겠고, 더불어 항균제 내성 또한 전파 될 수 있음을 예상하게 한다.

사람 유래 대장균의 경우 56.8\% 인 25주가 class 1 integron을 보유하고 있었고, 닭 유래 대장균의 경우 $32.3 \%$ 인 11주가 class 1 integron을 가지고 있었다. Gene cassette array의 경우 사람 유래 대장균의 경우는 한 주를 제외한 24주가 $d f \mathrm{~A} \mathrm{~A} 17-a a d \mathrm{~A} 5$ 를 가지고 


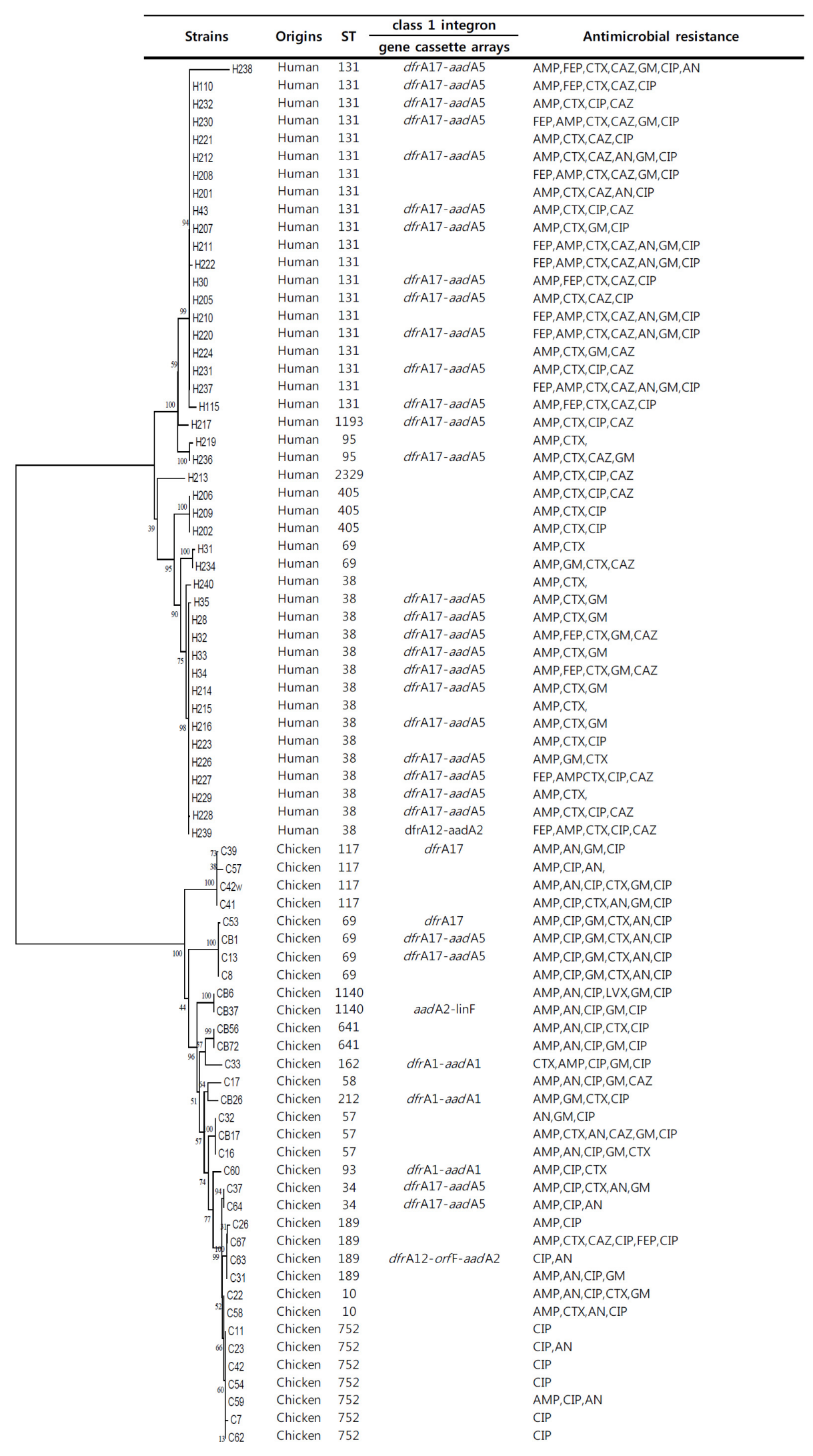

Fig. 1. Characteristics and phylogenetic tree based on MLST for E. coli isolates. 
있었는데, 닭 유래 대장균의 경우는 다양한 형태의 gene cassette array를 보유하고 있어 사람 유래 대장균과는 다른 양상을 보였다. 이러한 결과는 양계농장의 경우 대부분 집단밀집사육을 하고 있어 개체 간 유전자의 전파가 비교적 쉽기 때문일 것으로 예상 되어진 다. 이러한 현상에 대한 추가적인 연구가 필요 할 것으로 생각된다. 본 연구에서 충청지역의 사람유래 대장균과 닭 유래 대장균 사 이에 분포되어 있는 유전형의 차이가 큰 것으로 나타났다. 사람유 래 대장균과 닭 유래 대장균 모두 다양한 항균제에 내성을 보이는 것으로 나타났고, 특히 대장균의 경우 quinolone계 항균제에 높은 빈도의 내성률을 보였다. 또한 대다수의 대장균 분리주들이 integron 과 gene cassette array를 보유하고 있는 것으로 나타나 항균제 내 성 전파가 우려되는 결과를 나타냈다. 따라서 항균제에 대한 내성 균의 발생빈도를 줄이기 위해 항균제의 사용에 대한 관리와 더불어 지속적인 항균제 내성 모니터링이 필요할 것으로 사료된다.

\section{요 약}

최근 항균제의 광범위한 사용으로 인한 항균제 내성세균의 출현 과 확산이 축산환경에서 빈번하게 일어나고 있고 이렇게 출현한 다 제 내성세균은 사람에게 직접 전파될 수 있어 큰 문제가 되고 있다. 본 연구는 2013년 7월부터 2014년 7월까지 충청지역의 임상검체 $(\mathrm{n}=44)$ 및 양계농장의 닭 $(\mathrm{n}=34)$ 에서 분리된 78주의 대장균을 대상 으로 이루어졌다. PCR과 염기서열 분석을 통하여 MLST 분석과 class 1 integron의 유전형을 분석하였다. 항균제 감수성 검사는 디 스크 확산법으로 시행하였다. 사람 유래 대장균의 경우 ST131 $(n=20)$ 과 ST38 $(n=15)$ 이 가장 많았고 닭 유래 대장균은 ST752 $(n=7)$ 이 가장 많았으며 ST117, ST189, ST69는 각각 4주였다. 사 람에서 유래한 대장균은 총 44주 중 25주가 class 1 integron을 가 지고 있었다. 반면 닭에서 유래한 대장균은 총 34 주 중 11 주가 class 1 integron을 가지고 있었다. 충청지역에 분포되어있는 사람 유래 대장균과 닭 유래 대장균의 유전형 및 항균제 내성 패턴에 차 이를 보였다.

\section{Acknowledgements: None \\ Funding: None \\ Conflict of interest: None}

\section{References}

1. Clinical and Laboratory Standards Institute. Performance standards for antimicrobial susceptibility testing. Twenty third Informational supplement, M100-S23. Wayne, PA: Clinical and
Laboratory Standards Institute, 2013.

2. Dho-Moulin M and Fairbrother JM. Avian pathogenic Escherichia coli (APEC). Vet Res. 1999, 30: 299-316.

3. Dillon B, Thomas L, Mohmand G, Zelynski A, Iredell J. Multiplex PCR for screening of integrons in bacterial lysates. J Microbiol Methods. 2005, 62:221-232.

4. Felsenstein J. Confidence limits on phylogenies: An approach using the bootstrap. Evolution. 1985, 39:783-791.

5. Hong SG, Kang MS, Choi JR, Lee KW, Chong YS, Kwon OH. Molecular characteristics of extended-spectrum $\beta$-lactamases in clinical isolates of Enterobacteriaceae. Korean J Clin Pathol. 2001, 21:495-504.

6. Kim S, Sung JY, Cho HH, Kwon KC, Koo SH. Characterization of CTX-M-14- and CTX-M-15-Producing Escherichia coli and Klebsiella pneumoniae isolates from Urine Specimens in a Tertiary-Care Hospital. J Microbiol Biotechnol. 2014, 24:765770.

7. Klare I, Heier H, Claus H. Enterococcus faecium strains with vanA- mediated high- level glycopeptide resistance isolated from animal foodstuffs and fecal samples of humans in the community. Microb Drug Resist. 1995, 1:265-272.

8. Lee K, Lee HS, Jang SJ. Antimicrobial resistance surveillance of bacteria in 1999 in Korea with a special reference to resistance of enterococci to vancomycin and Gram negative bacilli to third generation cephalosporin, imipenem, and fluoroquinolone. J Korean Med Sci. 2001,16:262-270.

9. Maiden MC, Bygraves JA, Feil E, Morelli G, Russell JE, Urwin R, et al. Multilocus sequence typing: a portable approach to the identification of clones within populations of pathogenic microorganisms. Proc Natl Acad SCi USA. 1998, 95:3140-3145.

10. Neu HC. The crisis in antibiotic resistance. Science. 1992, 257:1064-1073.

11. Recchia GD and Hall RM. Gene cassettes: a new class of mobile element. Microbiology. 1995, 141:3015-3027.

12. Richet HM, Mohammed J, McDonald LC, Jarvis WR. Building communication networks: international network for the study and prevention of emerging antimicrobial resistance. Emerg Infect Dis. 2001, 7:319-322.

13. Rodriguez I, Barownick W, Helmucth R, Mendoza MC, Rodicio MR, Schroeter A, et al. Extended-spectrum $\beta$-lactamases and AmpC $\beta$-lactamases in ceftifur-resistant Salmonella enterica isolated from food and livestock obtained in Germany during 2003-07. J Antimicrob Chemother. 2009, 64:301-309.

14. Saitou N. and Nei M. The neighbor-joining method: A new method for reconstructing phylogenetic trees. Mol Biol Evol. 1987, 4:406-425.

15. Sung JY, Oh JE, Kim ES, Son JM, Kim HY, Lim DY. Spread of CTX-M Extended-spectrum $\beta$-lactamase Producing Escherichia coli in the Community in Chungcheong Area, Korea. Korean J Clin Lab Sci. 2013, 45:43-47.

16. Song S, Lee EY, Koh EM, Ha HS, Jeong HJ, Bae IK, et al. Antibiotic resistance mechanisms of Escherichia coli Isolates from urinary specimens. Korean J Lab Med. 2009, 29:17-24.

17. Tamura K, Nei M, Kumar S. Prospects for inferring very large phylogenies by using the neighbor-joining method. Proc Natl Acad Sci USA. 2004, 101:11030-11035.

18. Tartof SY, Solberg OD, Manges AR, Riley LW. Analysis of a ur- 
opathogenic Escherichia coli clonal group by multilocus sequence typing. J Clin Microbiol. 2005, 43:5860-5864.

19. Tamura K, Stecher G, Peterson D, Filipski A, Kumar S. MEGA6: Molecular Evolutionary Genetics Analysis version 6.0. Mol Biol Evol. 2013, 30:2725-2729.

20. Van Den Bogaard AE, London N, Stobberingh EE. Antimicrobial resistance in pig faecal samples from the Netherlands (five abattoirs) and Sweden. I Antimicrob Chemother. 2000, 45: 663-671.

21. White PA, McIver CJ, Rawlinson WD. Integrons and gene cassettes in the Enterobacteriaceae. Antimicrob. Agents Chemother.
2001, 45:2658-2661.

22. Willems RJ, Top J, van Den Braak N. Host specificity of vancomycin-resistance Enterococcus faecium. J Infect Dis. 2000, 182:816-823.

23. Winokur PL, Brueggemann A, DeSalvo DL, Hoffmann L, Apley $\mathrm{MD}$, Uhlenhopp EK, et al. Animal and human multidrug- resistant, cephalosporin-resistant Salmonella isolates expressing a plasmid-mediated CMY-2 AmpC $\beta$-lactamases. Antimicrob Agents Chemother. 2000, 44:2777-2783.

24. Witte W. Medical consequences of antibiotic use in agriculture. Science. 1998, 279:996-997. 